\title{
Heideggerovo a Kiekegaardovo pojetí svobody a odpovědnosti
}

\author{
Jiří Olšovský
}

Envigogika 2011/VI/2- Recenzované články/ Reviewed Papers

Publikováno/Published 30. 09. 2011

DOI: http://dx.doi.org/10.14712/18023061.61

\begin{abstract}
Abstrakt:
Německý filosof Martin Heidegger poprvé rozvrhl ve svém filosofickém myšlení radikální kritiku tradiční (starověké i novověké) metafyziky. Tato metafyzika, jež se dnes v podstatě projevuje především technickým a technologickým myšlením, zprostředkovaně způsobila současnou ekologickou krizi, a je u kořene necitlivého a stále ještě manipulativního př́stupu k prírodě. Novověká metafyzika, vzešlá vposledku z kartezianismu, je nesena antropocentrismem, tj. situací, kdy za základ všech hodnot se uznává jen člověk a jeho potřeby; ve všech oblastech praktického života se prosazuje jeho často zbytnělé já. A právě Heidegger je jedním z prvních myslitelů, kteří dali podnět k radikální revizi západního myšlení, jež je stále tvrdě metafyzické a antropocentrické. Takové myšlení je třeba překonat, jen tak se pole lidské svobody bude ve světě rozšiřovat méně egoisticky, člověk bude moci dál zdárně pobývat na světě v souladu se světem i svým vnitřním ustrojením.
\end{abstract}

Každou epochu vždy svým zprostředkujícím způsobem tvaruje filosofie, která připravuje půdu pro skutečné myšlení $v$ dalších oblastech teorie a praxe. Ač filosofické myšlení nikdy neovlivňuje prímo politiky a celkové společenské klima, určitým nepř́mým způsobem vždy působí a nakonec se pozitivně (či negativně) projevuje v celé skutečnosti. Jde vždy nakonec o celkovou změnu paradigmatu, právního prostředí, radikální změnu hodnotového systému apod. To je šance filosoficky působit, přivrátit myšlení, abychom tak řekli, na správnou cestu, kdy se na cestu nemanipulativního prístupu k prírodě dostane celá skutečnost.

Jak jsme již řekli, byl to Heidegger, který zde svým myšlenkovým rozvrhem sehrál $v$ tomto smyslu významnou iniciační roli. Právě on poukázal na to, že dnes je vskutku zapotřebí přivést nevýslovné slovo bytí k řeči, jen tak se dostaneme za zapomenutost na toto bytí a znovu tak začneme chápat posvátnost prírody. Jde o komplexní pohyb, na který nějaký "selský rozum" nestačí, kdy bude třeba podnítit celkovou proměnu člověka, transformovat jeho způsob vztahování se $k$ sobě i k celku světa a př́rody, a tedy proměnit jeho podstatnou duchovní existenci, aby $v$ brzké době nedošlo $\mathrm{k}$ zániku jeho existence fyzické - aby člověk na planetě Zemi ještě nějaký ten čas pobyl. Heidegger právě svým ekofenomenologickým a protimetafyzickým zamyšlením podstatným dílem přispěl k tomu, abychom spěli $k$ dosažení nového vědomí, jež povede $k$ dobrému pobytu na zemi ( $s$ výhledem na nebe). Proto je třeba psát o tomto typu myšlení, vzbouzet $v$ člověku naději, že se vyprostí $z$ dosavadního stále ještě dobyvačného prístupu $k$ prírodě; tehdy se lidská svoboda naladí na svobodu samého bytí a člověku se otevřou příznivější podmínky pro jeho nenásilné pobývání na zemi v souzvuku s přírodou. 


\section{Klíčová slova:}

Badatelsky orientované vyučování v přírodních vědách (BOVB), environmentální výchova, interaktivní tabule

\section{Abstract:}

This paper shows how by Heidegger and Kierkegaard the freedom arises from within the linkage on the light of being; in the coming-close to the light we become free. Our freedom at last lies in the relevant taking-over of the freedom of being, including our most proper possibility to exist. The thinker assumes the accountability for the mystery of being. The human being is by its very essence as corresponding to the being, in moderate releasement (Gelassenheit) he gives oneself to the truth of being. Only in this way can one disburden of modern-age metaphysical willing, and bring forth the truth in commensurability with the mystery of nature (letting-be).

\section{Key words:} whiteboard

Inquiry based science education (IBSE), environmental education, interactive 
Úvod

Tajemné působení filosofie tkví mimo jiné v probouzení naší svobody, kdy se jedinci může platónsky podařit přizpůsobit se světlu a osvobodit se k pravdě jsoucího. Naše svoboda i podle Heideggera povstává z vazby na světlo, v přibližování se ke světlu se stáváme svobodnými. Výstup ke světlu se tedy zobrazuje jako u Platóna jakožto proces pozitivního osvobození, dosažení skutečné svobody: v pohybu ke světlu bytí. Podobně i u Kierkegaarda je rozhodující zachránit existenci před slepým determinismem každodenní nouze a nutnosti; jen tak se lze otevírat svobodě v nekonečném pohybu věčnosti. Tehdy se odhaluje osobní pravda života lidské existence, skutečné dějiny jednotlivce $v$ zahlédnutí pravé dialektiky svobody a odpovědnosti. Pokusme se blíže osvětlit přístupy obou filosofü, $\mathrm{a}$ to s důrazem na vystupňovaný rozvrh Heideggerův. Bytí a život je třeba hájit a ochraňovat. Také vưči sobě a prírodě je třeba žít odpovědně, odpovídat sobě samému, druhým lidem a přirozenosti života. Jen tak Ize žít autenticky a vlastním způsobem v naladěnosti pravdy bytí. Svou zodpovědnost je třeba zjevně svobodně přijmout, a jen odtud se Ize rozvrhovat ke své nejvlastnější možnosti být, existovat v odpovídání ryzímu bytí a naslouchání přírodě, v jejím ochraňování.

\section{Úzkost a světlo svobody}

Jen ve volnosti a svobodě je podle Kierkegaarda možná ta pravá láskyplná „radost a věčná pohoda", ${ }^{1}$ která může vzniknout nejen mezi dvěma jedinci. Skutečná hra svobody mưže existovat i mezi člověkem a přírodou, kosmem. Lidé však svou svobodu nevyužívají, skutečně nemyslí, jen se utápějí v řečech - a jak vyzrát v pragmatismu dne. Kierkegaard ukazuje, jak na tom jsme: „Jak nerozumní jsou lidé! Nikdy nevyužívají svobody, jež mají, ale dožadují se těch svobod, jež nemají. Mají svobodu myšlení - vyžadují svobodu mluvení."2

Pro člověka však existuje možnost svobody. To je u Kierkegaarda spojeno s možností vysvobození z úzkosti. Člověk se může svobodně rozhodnout, odhodlat se ke svému bytostnému určení, překonat těžkosti "spícího ducha" (což je vždy spjato s úzkostí) a přejít na stranu poznání dobra a zla, na stranu poznání sebe sama. v tomto riskantním odhodlání může u Kierkegaarda skokově povstat člověk jakožto skutečný duch.

A čím je dále u Kierkegaarda vůbec vzbuzena sama úzkost? Je to sama lidská svoboda, její možnost, jež mủže vést k úzkosti. Úzkost se objevuje s možností svobody, s možností stát se sám sebou. Svoboda (stejně jako věčnost v nitru) je $v$ člověku př́tomna potenciálně jako možnost; jde o to, ji v sobě najít a realizovat. Možnost svobody s sebou nese další vznik úzkosti, nebot' tu jde o odkrytí sebe sama, což je spjato s určitým úzkostným úsilím, kdy se obracíme do vlastního nitra. Úzkost tu vzchází jako úzkost před svobodou, před možností ničeho, před možností sebeztráty v ničem. ${ }^{3}$

Úzkost je Kierkegaardovi závratí svobody: lidský duch chce klást syntézu, tj. kierkagaardovskou syntézu možnosti a skutečnosti, věčnosti a časnosti, svobody a nutnosti, těla a ducha, nalézá však jen svou konečnost a provinilost. $V$ úzkosti se tedy ještě svoboda plně neuskutečnila, je tudíž "bezmocnou". Kierkegaard proto mưže obrazně napsat: "Úzkost je určitá ženská bezmoc, v níž se stává svoboda bezmocnou..."4 Završeně

\footnotetext{
${ }^{1}$ S. Kierkegaard, Svůdcův deník, přel. R. Kejzlar, Mladá fronta, Praha 1970, s. 75.

2 S. Kierkegaard, Either/Or, Part 1, in: týž, Kierkegaard's Writtings, III, ed. a přel. H. V. Hong, E. H. Hong, Princeton University Press, Princeton, New Jersey 1987, s. 19.

3 Srv. mou práci Niternost a existence. Úvod do Kierkegaardova myšlení, Akropolis, Praha 2005, s. 73-86.

4 S. Kierkegaard, The Concept of Anxiety, ed. a přel. R. Thomte, A. B. Anderson, Princeton University Press, Princeton, New Jersey 1980, s. 61.
} 
se uskutečnit ve své svobodě bude znamenat autenticky stupňovat svého ducha, realizovat v sobě bytostnou syntézu, odevzdat se božskému bytí.

Pro Heideggera je otázka svobody též něčím veledůležitým, je základním problémem filosofie. "Otázka po bytnosti lidské svobody je tedy základní otázkou filosofie, v níž je dokonce zakořeněna otázka po bytí." 5 v práci O bytnosti lidské svobody z roku 1930 Heidegger ukazuje, že otázka svobody je v tradiční metafyzice a u Kanta otázkou druhu kauzality a klade si otázku, zda musí být svoboda pojata jako druh kauzality, nebo zda právě naopak kauzalita je problémem svobody. Zjištuje, že "kauzalita je právě ve smyslu tradičního rozumění bytí jsoucího, $v$ běžném rozumění stejně jako $v$ tradiční metafyzice, základní kategorií bytí jakožto výskytovosti". ${ }^{6}$ Jedním z možných určení bytí jsoucího (mezi jinými určeními) je tudíž kauzalita.

Kauzalita zůstává problémem svobody, a to pro Heideggera ovšem znamená, že do problému svobody je zabudována otázka po bytí; půjde mu o to, uchopit skutečnost svobody jakožto problém bytí. Kauzalita se prostě doposud nestala předmětem radikálního zamyšlení, jež by vedlo k problému bytí. Bytnost svobody nám tudíž zatím zůstala uzavřena. Kdy dojde k tomu, že se nám bytnost svobody otevře? Heidegger odpoví svým charakteristickým způsobem: když my sami budeme "bytostně v bytnosti", když budeme odpovídat bytí.

Potkat se vskutku se jsoucnem a vztahovat se k němu po způsobu zjevnosti Ize podle Heideggera jen tam, kde je svoboda. "Svoboda je podmínka možnosti zjevnosti bytí jsoucího, porozumění bytí."7 Tak se i kauzalita zakládá ve svobodě, problém kauzality je problémem svobody, nikoli naopak. Principiálně je otázka po bytnosti svobody Heideggerovi základním problémem filosofie, a to jedině tehdy, jak již vidíme, jestliže její vưdčí otázka právě spočívá $v$ otázce po bytí. K tomu je však třeba pojmout člověka v základu jeho vlastního bytí, uchopit ho v jeho bytostné přirozenosti; dosahovat ze základu své bytosti (svého pravého já) skutečně svobodného bytí a chtění a tím i filosofování.

Je dále třeba umět rozlišovat mezi stíny a skutečnými věcmi, uskutečnit v sobě toto rozlišení. Toto uskutečnění znamená pro člověka i skutečně existovat, dosahovat pravého lidství - jak Heidegger ukazuje v díle O bytnosti pravdy z let 1931/32 (jež je věnováno Platónově podobenství o jeskyni). Jen tak Ize uchopit neskrytost samu, dění neskrytosti samé. Tehdy se přibližujeme k bytnosti pravdy jako neskrytosti. Nezdarem je odklon od světla, návrat k poutům. Skutečným osvobozením je nasměrování se ke světlu, „příklon ke světlu". 8 Vzestup ke světlu vyžaduje práci a úsilí, jde o namáhavou, úzkostnou cestu. Heidegger může napsat: "Skutečné osvobození ... vyžaduje zároveň výdrž a odvahu..." Jde o osvobozování se pro světlo, světlo bytí, o sžívání se s tímto světlem; zároveň půjde o odstoupení od horečnaté činnosti mezi stíny a prokouknutí marné slávy apod.

Světlo mimo jeskyni je nakonec, jak píše Heidegger, když vykládá Platóna, "smyslovým obrazem nejvyšší ideje". Jedinci se může podařit ze sebe, z vlastního úsilí přizpưsobit se světlu, osvobodit se tak k "neskrytosti jsoucího". 10 Platónovo podobenství o jeskyni v nás může probouzet sám vztah k pravdě jako neskrytosti, otevře se nám třeba jednou bytnost pravdy; $v$ tom tkví tajemné pưsobení filosofie.

5 M. Heidegger, Vom Wesen der Menschlichen Freiheit. Einleitung in die Philosophie, in: týž, Gesamtausgabe, Bd. 31, V. Klostermann, Frankfurt am Main 1994, s. 300.

6 Tamtéž.

7 Tamtéž, s. 303.

8 M. Heidegger, Vom Wesen der Wahrheit. Zu Platons Höhlengleichnis und Theätet, in: týž, Gesamtausgabe, Bd. 34, V. Klostermann, Frankfurt am Main 1988, s. 38.

9 Tamtéž, s. 43.

10 Tamtéž, s. 44. 
Ideu zjevně nevidíme tělesnýma očima, tu můžeme uvidět jen zvláštním zřením. Idea není nic jsoucího. To, co rozumově nazřeme (jde o druh intelektuálního zření), je "cobytî", to, "čím věc je - její bytî". Heidegger také napíše, že co-bytí je "totožné, to obecné pro mnohé". ${ }^{11}$ "Nad" jsoucny jsou tedy, platónsky řečeno, ideje jako cosi podstatnějšího než stíny věcí. A Heidegger dále mưže komentovat: „V ideji zahlédneme to, co každé jsoucí je a jak je, krátce: bytí jsoucího."12 Jde tu o platónské zření idejí, o mohutnost postřehování svým rozumem (nús). Vězni v jeskyni vidí pouze stíny, jsoucna, chybí jim porozumění pro bytí. Proto vězni, nebo alespoň jeden z nich, musí „pryč od jsoucen..., od stínů... Musí uskutečnit vzestup..., vystoupat k jasu dne, na světlo, $k$,idejím' ". ${ }^{13}$ Jas světla, jak chápeme, není něčím jsoucím, je neuchopitelný, je to prázdné neuchopitelno samo. Idea pak nechává uvidět, co je jsoucí, jeho bytí. „Bytí, idea, je to propouštějící: světlo."14

Z uvedeného je zřejmé, že naše svoboda povstává z vazby na světlo. Světlo totiž poskytuje svobodu. $v$ tomto počínání se stáváme svobodnými. Vidíme teprve od bytí, od toho, čemu porozumíme $v$ jeho konkrétním bytí. Ve světle ideje rozumíme smyslu bytí. Výstup na světlo dne takto zobrazuje proces pozitivního osvobození, dosažení skutečné svobody, a to v pohybu ke "světlu samému". Zahlédnutí světla je "rozvrhem byti". ${ }^{15}$

\section{Bytnost pobytu a svoboda}

$\checkmark$ roce 1929 Heidegger publikuje dílo O bytnosti důvodu. Zde se ukazuje (dva roky po vydání Bytí a času), že konečnost, faktická, tj. vržená uvlastněnost pobytu (Dasein) svědčí také o jeho bytostné propastnosti. Pravda bude mít svůj základ v propastné nepřítomnosti základu. Propastnost pobytu se nedá rozevřít z nějakého psychologického přístupu a rozčlenění, jak zdưrazňuje Heidegger. Pobyt musí v rozvrhujícím překračování světa překročit sebe sama, transcendovat se, aby si mohl z tohoto umocnění vůbec teprve rozumět jakožto „propast". Pak: z naší konečné a „propastné" svobody povstává náš možný rozvrh světa. Heidegger může napsat: "Svoboda je základem dưvodu [Grund des Grundes]. (...) Základní bytí svobody nemá ... charakter jednoho ze zpưsobů zdůvodňujícího zakládání, nýbrž se určuje jako zakládající jednota transcendentální přísnosti důvodění. Jakožto tento základ je však svoboda důvodové povahy zbavený základ [Ab-grund] pobytu. Ne že by bylo jednotlivé počínání bez základu, nýbrž svoboda klade ve své bytnosti jako transcendence pobyt jakožto moci-být do možností, jež se před jeho konečnou volbou, tj. ve svém osudu, rozevírají."16 Základ jakožto svoboda (transcendence) se tu stává propastným, důvodové povahy zbaveným základem ( $A b$ grund) pobytu. Sama svoboda klade pobyt do svých možností. Co je to vlastně za svobodu?, Ize se ptát.

Vodítkem zde může být věta: „Rozevření propasti v zakládající transcendenci je spíše prvotním pohybem, který svoboda s námi samými uskutečňuje a dává se nám tak ,k pochopení..." 17 Svoboda sama nás tedy rozpohybovává a rozevírá propast v zakládající transcendenci našeho tubytí, $v$ "srdci" našeho pobytu. Tato svoboda je svobodou bytí samého, svoboda jakožto propast, jakožto „propastný základ”, svoboda bytování pravdy

11 Tamtéž, s. 5.

12 Tamtéž, s. 52.

13 Tamtéž.

14 Tamtéž, s. 57

15 Tamtéž, s. 60. u Kierkegaarda byla myšlenka lidské svobody rozvinuta v souvislosti s pojetím prožretelnosti a boží vlády. Srv. Søren Kierkegaard's Journals and Papers, Vol. II, (1231), ed. a přel. H. V. Hong, E. H. Hong, Indiana University Press, Bloomington and London 1975. (Dále jen JP, číslo svazku a záznamu.)

16 M. Heidegger, Vom Wesen des Grundes, in: týž, Wegmarken, in: týž, Gesamtausgabe, Bd. 9, V. Klostermann, Frankfurt am Main 1976, s. 174.

17 Tamtéž. 
ryzího bytí (Seyn). Tato svoboda nechává povstat nouzi či potřebu bytí jakožto „vzmach základu", z něhož mohou vzejít lidé i bozi s jejich nouzí a potřebou. ${ }^{18} \mathrm{U}$ Heideggera posléze z nouze opuštěnosti bytím vzchází i myslivější myšlení; toto myšlení pak přivádí opět na myslivou cestu právě ono původní bytí, jak se to zračí v Heideggerových větách z roku 1949: „Že se zde a jak se zde bytí samo obrací k myšlení, nezáleží nikdy především a pouze na myšlení. To, že a jak je myšlení bytím zasaženo, přivádí myšlení k tomu, že vytryskne z bytí samého, aby tak bytí jako takovému odpovídalo."19 Z důvodu své vlastní nouze bytí chce, aby myšlení bylo, jen tak bytí svým způsobem může být; a zpětně - v odpovídání - může být i myšlení. Bytí tu předává myšlení jistou svobodu - a myšlení se osvobozuje k sobě samému.

Vidíme, že u Heideggera vzniká diference v pojetí svobody vưči tradičním metafyzickým teoriím svobody. Otevírá se tu bytostně dějinná ontologie ryzího bytí jakožto ontologie osvobozující. Rozvrhující člověk se rozvrhuje jako svobodný, osvobozený od jsoucen. Ve hře je však zároveň primárně osvobodivé pưsobení ryzího bytí (a s ním spjatá ontologie).

To, co je osvobozující v této ontologii, je Heideggerovo bytostně dějinné myšlení samo. Metafyzické doktríny usilují o osvobození se od jsoucna, ale toto heideggerovské znamená osvobození se od jsoucího kvůli ryzímu bytí. Toto myšlení se svobodně rozvrhuje vưči ryzímu bytí. Zároveň je samozřejmě svobodné od Ipění na jsoucnech; od jsoucen je třeba se oddálit a navrátit se k uvlastňujícímu vrhu ryzího bytí. Bytostně dějinné (počáteční) myšlení pak „opouští a odvrhuje vše běžné, neočekává nic bezprostředně ze jsoucna". ${ }^{20}$ Mưže tryskat z přináležitosti k uvlastňujícímu ryzímu bytí.

Kierkegaard mluvil analogicky o přináležitosti a bezpodmínečné odevzdanosti bohu. Napsal: "'Vážnost' je právě zvolit Boha bezprostředně a ,především'."21 Když se odevzdáváme jen jsoucímu a své egoistické svobodě volby, pak ztrácíme svou svobodu. Jde o to, "vybrat boha", přiblížit se božskému bytí. To Ize pouze v určitém naladění "bázně a chvění" a v dosažení vyššího paradoxního stadia, kterému říkal eticko-náboženské stadium paradoxní zbožnosti. ${ }^{22}$

\section{Svoboda jako bytostné určení pravdy}

Pravda Heideggerovi původně nesídlí ve větě, a tak mu „vyvstává otázka po základu vnitřní možnosti otevřeného a směrnici předem dávajícího vztahování, možnosti, která jediná propůjčuje větné správnosti titul, že vůbec splňuje bytostné určení pravdy". ${ }^{23}$ Zjevné, přítomné jsoucí se stává měřítkem a směrnicí pro představující shodu (výpověd' je pravdivá, když souhlasí, ladí s věcí). Otevřené vztahování pobytu si musí toto měřítko nechat přikázat. Pak ovšem musí to, co teprve správnost umožňuje, platit pưvodněji za bytnost pravdy.

Heidegger zde nově vyjadřuje moment, kdy nikoli že by pobyt sám ze sebe kladl měř́tka a směrnice, kterými poměřuje věci, nýbrž jako by nechával na sebe působit určitou směrnici vycházející ze jsoucen. Rozvrh pobytu tu není (oproti ještě spíše

18 M. Heidegger, Beiträge zur Philosophie (Vom Ereignis), in: týž, Gesamtausgabe, Bd. 65, V. Klostermann, Frankfurt am Main1989, s. 470. (Dále jen GA 65 a číslo stránky.)

${ }_{19}$ M. Heidegger, Úvod k přednášce "Co je metafyzika?", in: týž: Co je metafyzika, přel. I. Chvatík, Oikúmené, Praha 2006, s. 13.

${ }^{20}$ GA 65, s. 227

21 JP II (1261)

22 Viz Niternost a existence, c. d., s. 140.

${ }^{23}$ M. Heidegger, O pravdě a Bytí, přel. J. Němec, Mladá fronta, Praha 1993, s. 27. (Dále jen PB a číslo stránky.) 
decizionistickému pojetí v Bytí a čase) nějakým představujícím kladením a výkonem subjektivity, nýbrž se tu začíná objevovat „ekstatický” vztah k pravdě bytí. Heidegger se tedy ptá, co předem dává určitou směrnici pobytu v jeho otevřeném vztahování ke jsoucnu. V očích Heideggerových - kdo vlastně přikazuje měřítko? Již tušíme odpověd': je to „vyzařování" bytí samého, jež skýtá míru pro lidské počínání.

Jestliže pravda původně nesídlí ve větě, co je to za základ, který umožňuje shodu, který poskytuje směrnici pro naše vztahování se ke jsoucnu? Odkud má představující vypovídání našeho pobytu př́kaz řídit se předmětem, jak se může vůbec dít něco takového jako: dostat předem prríkaz ke shodě?

Heidegger tu hovoří o „předchozím dávání (Vorgeben) příkazu ke sladění, kdy se pobyt posléze uvolňuje do otevřeného pole světa "vưči působícímu z něj zjevnému", mluví o sebeuvolnění pobytu pro závazný směr na základě př́kazu "spravovat se předmětem a souhlasit na základě správnosti". Toto sebeuvolnění pro závazný směr je nyní pro Heideggera možné díky svobodné volnosti pobytu: "být svoboden vưči zjevnému v otevřeném poli". Svoboda se takto stává bytností pravdy: "Otevřený postoj vztahování jako vnitřní umožnění správnosti je založen na svobodě. Bytostným určením pravdy je svoboda." 24

Je zřejmé, že vnitřní umožnění správnosti je umožněno svobodou otevřeného vztahování pobytu. Na co se jeho otevřené vztahování vztahuje, není pouhé jsoucno, je to jsoucno, jak je samo o sobě (jako takové). Toto "je” je bytí jsoucího. Zbývá už jen „položit se" do bytnosti zjevnosti jsoucího, a tak ho "nechat být". Takto můžeme být svobodni ve svém pobytu vưči světu, vưči jednotlivým jsoucnům světa. Svoboda je tudíž posledním základem možnosti pravdy jakožto správnosti a musí být jmenována bytností pravdy. Svoboda pobytu nachází svou závaznost v tom, k čemu je svobodná. Sebeodevzdání svobody pro závazný směr se děje jako svobodné bytí k zjevování světa. "Svoboda vưči zjevnému $v$ otevřeném poli nechává příslušné jsoucno být vždy oním jsoucnem, jímž je. Svoboda se ted' odhaluje jako nechání jsoucna být." 25 Bytností ontologického postoje je: „"nechat být". Lidská svobodná existence je pak samo nechávání-být. Pobyt přichází ve své transcendenci ke jsoucnu a nechává ho, čím je a jak je. Sebeodevzdání pobytu má „ekstatickou" povahu, pobyt tu stojí mimo sebe v napřažení k otevřenému poli světa (je vystaven či otevřen tomuto poli).

Toto nechání-jsoucna-být samož̌ejmě není nějakou Ihostejností či opomíjením, jak Heidegger zdưrazňuje, jde spíše o "sebeoddání se jsoucnu”, kdy se nechává jsoucno být tím, čím je - v otevřeném poli světa. Jde o takovou strukturu vztahování se ke jsoucnu, kdy se otevřený pobyt oddává ( $v$ odevzdanosti) otevřenému poli světa $v$ jeho otevřenosti, otevírá se odevzdaně zjevenému jsoucímu v jeho bytí, a tak ho nechává přijít ke slovu, k pravdě a neskrytosti. Výpověd' se tu řídí jsoucím, přijímá od něho měřítko a směrnici. Sebeoddání se jsoucnu je zároveň jistým „poodstoupením od jsoucna” (distance), aby se toto jsoucno ukázalo jako to, čím je a jak je.

Pobyt se může osvobozovat k zjevování jsoucího v jeho pravdě. Poznávající pobyt se váže (ladí) na jsoucí - a nechává ho být; věci a příroda se "nechávají být". Tato ponechávající svoboda je „v sobě se vy-stavující, ek-sistentní". Bytnost svobody spatřená s ohledem k bytnosti pravdy je Heideggerem nyní tedy určena jako "vystavení do odkrytosti jsoucna". ${ }^{26}$ Jsoucí se může skrze eksistentní sebeoddání ukázat v tom, co je, ve své pravdě. Svoboda jakožto nechání-věci-být, ponechání jsoucna tím, čím je, umožňuje, že věci jsou osvobozovány ke své bytostné dimenzi.

\footnotetext{
${ }^{24}$ Tamtéž, s. 31.

25 Tamtéž, s. 37.

26 Tamtéž, s. 39.
} 
Pobyt v pojednání o bytnosti pravdy začíná vystupovat jako tu-bytí (Da-sein) se svým základem, se svou "ek-sistencí" (jež samozřejmě nemá, jak víme již z Bytí a času, onticky existenciální význam). Eksistence je tu vystavením do odkrytosti jsoucna v celku, přičemž je zakořeněná $v$ pravdě jakožto svobodě. Pravda je ve své bytnosti svoboda, a člověk má možnost nechat jsoucno být, čím je (anebo ho nenechat, čím je).

Jak vidíme, člověka k jeho svobodě osvobozuje eksistentní tubytí jakožto necháníjsoucna-být. Ne že by však podle Heideggera nyní měl člověk svobodu jako vlastnost. Platí pravý opak: "svoboda, ek-sistentní, odkrývající tu-bytí má člověka, a to s takovou pưvodností, že jedině svoboda poskytuje lidem návaznost na jsoucno v celku jako takové, návaznost zakládající a vyznačující veškeré dějiny. Pouze ek-sistentní člověk je dějinný."27 $\mathrm{K}$ tomu musí být sám pobyt člověka svobodný (základ jako konečná svoboda našeho tubytí). Ke svobodě pak, jak je patrné z těchto Heideggerových úvah a náznaků a jak plyne i z našich výše zmíněných úvah, člověka přivádí samo bytí. Mưžeme říci, že člověk existuje jako vlastnictví svobody bytí: „.... ek-sistentní svoboda jako bytostné určení pravdy není vlastností člověka, nýbrž člověk ek-sistuje jen jako vlastnictví této svobody...", ${ }^{28}$ a to na základě vlastního sebepromýšlení: tehdy lidské bytí odpovídá pravdě bytí. ${ }^{29}$ Tak svoboda pobytu čerpá své bytostné určení z původnější bytnosti pravdy bytí. Pravda je odkrytost bytí, pravda bytí. Bytí je zdroj své vlastní pravdy. ${ }^{30}$

Můžeme tedy definitivně poznamenat, že svoboda pobytu je otevřena svobodě bytí samého a "nechává ho být". Výrazem naší vlastní svobody však samozřejmě zůstává naše výrazná schopnost volit mezi autentickou (opravdovou) a neautentickou existencí. Svoboda vede k sebeosvobozování vlastní svobody, vlastního tubytí. Svoboda však koneckonců pramení z bytí, teprve osvobodivé „volání byti"31 nás povolává. Ryzí bytí tu především „volá" k přípravě pro „jiný počátek”, přivádí naši bytnost ke svobodě, umožňuje svobodu pobytu $v$ jeho směřování $k$ bytostné dimenzi věcí. Heideggerovi tudíž to, co je svobodné v nejpůvodnějším smyslu, není pobyt, nýbrž bytí. A pobyt jakožto tu-bytí je pak zde-svobodou bytí. Bytí tudíž ve své účinné moci nad pobytem (a ve své "touze" po něm) utváŕi pobyt jako svobodný, tj. jako existenci ekstaticky otevřenou svobodě bytí samého. Vlastní svoboda pobytu tak povstává ze svého původu v bytí. Proces "světlení bytí může člověk stvrdit svou svobodou, svobodou svého "básnění, myšlení, budování". Vždy půjde o sebeodevzdání svobody pobytu onomu volání bytí. $V$ autentickém naplnění lidského bytí (tubytí) - v přijetí plnosti svobody - vzniká možnost původního zakládání pravdy, což se konkrétně děje při otevření existence světu. Součinnost našeho pobytu při odkrývání pravdy je neoddiskutovatelná, nicméně Heidegger nyní (po tzv. obratu), kdy pobyt již neznačí primát člověka a lidského bytí, nýbrž tubytí je nyní dějinným otevřením pravdy bytí, "bodem obratu v proměně/ zvratu uvlastňování", 32 zdůrazňuje, že tato aktivita je něčím závislým na pravdě ryzího bytí.

\section{Svoboda, pravda a nechání-být}

Viděli jsme, že bytnost pravdy se u Heideggera koneckonců ukazuje jako svoboda, jež je odkrývajícím necháním jsoucna být. Jak píše Heidegger také v pojednání o bytnosti pravdy (z roku 1943): "Svoboda vưči zjevnému v otevřeném poli nechává př́slušné jsoucno být vždy oním jsoucnem, jímž je. Svoboda se ted' odhaluje jako nechání jsoucna

\footnotetext{
27 Tamtéž, s. 41 .

28 Tamtéž, s. 43.

${ }^{29}$ Bytnost pravdy je "ono skrývající se jediné jedinečných dějin odkrývání ,smyslu' toho, co nazýváme bytím..." (tamtéž, s. 71)

${ }_{30}$ ".... pravda je původní pravdou bytí (uvlastňování)", jak píše Heidegger ve svých Př́spěvcích, GA 65, s. 329.

31 Srv. např. GA 65 , s. 384.
}

32 GA 65, s. 311. 
být. "33 Lidská svoboda je tak ekstatickou odevzdaností do "světliny byti", 34 do onoho tubytí, jež nechává bytí být. Lidská svoboda se adekvátně dosahuje v odevzdanosti, jež odpovídá stavu nechání-bytí-být. Je tudíž třeba překonat metafyziku technické a technologické "vưle k vưli", jež strhává člověka a přírodu do soukolí machinace a antropocentrické kalkulace. ${ }^{35}$ Neklade se více nárok panství vưči jsoucnu, získává se odstup od onto-theo-ego-logického přístupu ke jsoucnu, prolad'ovaného doposud "vưlí k moci". Náš pobyt, vznešená síla jeho existence, se zdrženlivě uvolní v klidu a tichu jasné a pokorné meditace, aby se mohla ukázat pravda bytí.

Heidegger takto opouští "svobodu" metafyziky subjektivity a začíná myslet (po roce 1936) svobodu jako eksistování ve světlině bytí, aby se pravda jsoucího mohla vyjevit (nechat-bytí-být).

V tomto sebeoddání světlině bytí podle Heideggera platí, že právě "svoboda již naladila každé vztahování na jsoucno v celku". ${ }^{36}$ Člověk tu zajisté nevlastí svobodu, spíše platí opak: svoboda, eksistentní, otevírající tu-bytí má člověka. Zároveň tu podle Heideggera nejde o nějakou naši ontickou náladu, pocit, prožitek. Naše eksistentní naladění je již vždy nějak naladěno, odtud se může dít naše odevzdané nechání-jsoucnabýt, naše dějinné vztahování; je doslova "proladěno otevřeností jsoucna v celku". ${ }^{37}$

To, co nás však vskutku ladí, je u Heideggera - jinak řečeno - koneckonců skrytí či skrytost jsoucna $v$ celku, tj. bytí samo. Skrytost tohoto bytí je to, co teprve ze sebe propouští (skýtá) podle heideggerovské ontologie jsoucno ke zjevu. Skrytost je zde bytí samo, ryzí bytí (Seyn, Es gibt). Tento předchưdný „počátek/ zdroj" umožňuje, aby se ukazovala neskrytost (je skýtána do prosvětlené otevřenosti světa), a to v základním procesu zjevování. Jinými slovy, skryté dávání bytí a času je zároveň jak skryto (neprítomno - což je dáno sebeskrytím bytí samého), tak je poskytováno jakožto jsoucno do svého zjevu. Odtud také pro Heideggera vyplývá, že naše odkrývání jsoucího je zároveň skrýváním jsoucna v celku. Naše eksistentní nechání-být je niterně zároveň určitým zakrýváním, což je dáno naší konečností. Sumárně Ize pak s Heideggerem napsat: v eksistentní svobodě pobytu se děje skrytí jsoucna v celku, "skrytost jest". 38

Skrytost jsoucna v celku tituluje Heidegger i jako „vlastní ne-pravdu”, jež je "starší než jakákoli zjevnost toho či onoho jsoucna. Je také starší než samo nechání být, odkrývající tak, že již udržuje v skrytosti a vztahuje se k skrytí". ${ }^{39}$ Vztaženost k skrytí, jež nese naše nechávání jsoucna být, je pak udržována skrytím skrytého $v$ celku, které Heidegger nazve také tajemstvím. I naším pobytem proniká tajemství (bytí). Odkrývající nechávání-být je tak i skrýváním (náš pobyt proniká skrytí skrytého, tajemství bytí). Eksistující tubytí v sobě podržuje původní neodkrytost, "vlastní ne-pravdu". Paradoxně řečeno, bytností pravdy je nepravda. Z uvědomění si těchto skutečností pak „vědoucí" může svobodně zakoušet samu pravdu bytí.

Lidský pobyt u Heideggera vposledku spočine v klidu a tichu jasné, vznešené a pokorné meditace (Gelassenheit). ${ }^{40}$ Tato zdrženlivá uvolněnost odevzdanosti se projevuje i v nechání-být-př́rody. Takto se může ukázat pravda bytí. Člověk se vposledku osvobozuje od manipulativního zjednávání, vstupuje do takového zacházení s věcmi, jež

33 PB, s. 37.

34 Srv. B. W. Davis, Heidegger and the Will. On the Way to Gelassenheit, Northon University Press, Evanston Illinois 2007, s. 121

35 Záchrana od technické vůle k vůli může vzejít z úplné proměny člověka, což se zprvu může podařit těm „nejodvážnějším”. Srv. např. M. Heidegger, Wozu Dichter?, in: týž, Holzwege, in: týž, Gesamtausgabe, Bd. 5, V. Klostermann, Frankfurt am Main 1977, s. 296.

36 PB, s. 47

37 Tamtéž.

38 Tamtéž, s. 49.

39 Tamtéž, s. 53.

40 Srv. M. Heidegger, Discourse on Thinking, Harper and Row, Publishers, New York 1966, s. 84 nn. 
neškodí ani člověku, ani př́rodě; zakouší uvlastňující událost (Ereignis). V odevzdanosti vzchází nové (hlubší) pochopení bytí a času, lidské nitro se otevírá pravdě bytí. $V$ odevzdanosti se pak i věci ukážou $v$ tom, co jsou, člověk pobývá na zemi jako autenticky svobodný, odevzdaný pravdě. Konkrétně pak bude záležet na naší odpovědnosti vưči životu a prírodě, zda budeme nacházet naši vlastní autentickou svobodu a pobývání $v$ naladění na pravdu, $v$ nechání-bytí-být, $v$ svobodné odevzdanosti a zdrženlivosti, anebo zda se utopíme ve svévoli bezbřehé subjektivistické vưle $k$ vưli, která vede k zániku. Odevzdanost znamená popření metafyzického novověkého (karteziánského) chtění, odevzdání se pravdě bytí a prírody. U Heideggera se tak setkáváme s výraznou snahou vyprostit se z vůle a chtění, s pokusem dosáhnout ne-chtějící svobody nechání-být a odevzdání tajemství bytí, kdy na cestě jasného a nerozptýleného vědění "dozrává vědoucí jasnost". ${ }^{41}$

Také u Kierkegaarda jde o skok do skutečného života: $v$ tom spočivá umění existence, která se zbavuje "hříchu" i ve vztahu k př́rodě, prohlubuje svou niternost a odevzdává se absurdnu absolutna (tajemství bytí); v bázni a chvění dospíváme ke skutečné proměně života, ke skoku ${ }^{42}$ do nemetafyzického myšlení nedestruujícího svět.

Myslitel přejímá odpovědnost za tajemství světliny bytí, dbá o ni, prodlévá v ní. Lidská svoboda je podřízena svobodě bytí, jež překračuje lidské bytí. Tak se ukazuje lidská nemetafyzická účast na svobodě (bytí) a odtud i plynoucí odpovědnost. Člověk jest bytostně jakožto odpovídající bytí, a naopak bytí potřebuje bytostnou účast člověka. Tubytí a původní bytí si mohou vzájemně bytostně odpovídat. ${ }^{43}$ Půjde tedy také o to, jak jsme schopni se vrátit k původnímu odpovědnému pobytu, jenž by byl s to participovat na ryzím bytí a jeho svobodě.

\section{Literatura}

- $\quad$ Davis, B. W. (2007). Heidegger and the Will. Evanston, Illinois: Northon University Press.

- Heidegger, M. (1968). Polní cesta. Orientace, 3(4),

- Heidegger, M. (1966). Discourse on Thinking. New York: Harper and Row, Publishers.

- HeIDEgGeR, M. Holzwege, in: Týž, Gesamtausgabe, Bd. 5, V. Klostermann, Frankfurt am Main 1977 (1977). .

- Heidegger, M. (1993). O pravdě a Bytí. Praha: Mladá Fronta.

- Heidegger, M. (2006). Co je metafyzika. Praha: Oikúmené.

- HEIDEgGeR, M. Beiträge zur Philosophie (Vom Ereignis), in: Týž, Gesamtausgabe, Bd. 65, V. Klostermann, Frankfurt am Main1989 . .

- HEIDEgGeR, M. Vom Wesen des Grundes, in: Týž, Wegmarken, in: týž, Gesamtausgabe, Bd. 9, V. Klostermann, Frankfurt am Main 1976 . .

- HeidegGer, M. Vom Wesen der Menschlichen Freiheit. Einleitung in die Philosophie, in: Týž, Gesamtausgabe, Bd. 31, V. Klostermann, Frankfurt am Main 1994 ..

- HEIDEgGeR, M. Vom Wesen der Wahrheit. Zu Platons Höhlengleichnis und Theätet, in: Týž, Gesamtausgabe, Bd. 34, V. Klostermann, Frankfurt am Main 1988 . .

\footnotetext{
${ }^{41}$ M. Heidegger, Polní cesta, přel. A. Geuss, in: Orientace č. 4, roč. III, 1968, s. 88.

42 Viz kapitolu Pojmy pohybu a skoku v mé knize Niternost a existence, c. d., s. 198-217.

${ }^{43}$ Srv. GA 65, s. 357.
} 
- $\quad$ Kierkegaard, S. (1980). The Concept of Anxiety. Princeton, New Jersey: Princeton University Press.

- KIERKEGAARD, S. Either/Or, Part 1, in: Týž, Kierkegaard's Writtings, III, ed. a přel. H. V. Hong, E. H. Hong, Princeton University Press, Princeton, New Jersey 1987 . .

- $\quad$ Kierkegaard, S. (1970). Svůdcưv deník. Praha: Mladá fronta.

- Olšovský, J. (2005). Niternost a existence. Úvod do Kierkegaardova myšlení. Praha: Akropolis.

- Søren Kierkegaard's Journals and Papers, Vol. II . Bloomington and London: Indiana University Press. 
Časopis Envigogika vydává Centrum pro otázky životního prostředí UK. Vývoj časopisu je podpořen projektem OP VK Mezioborová sít udržitelného rozvoje.

Více najdete na internetových stránkách projektu mosur.czp.cuni.cz
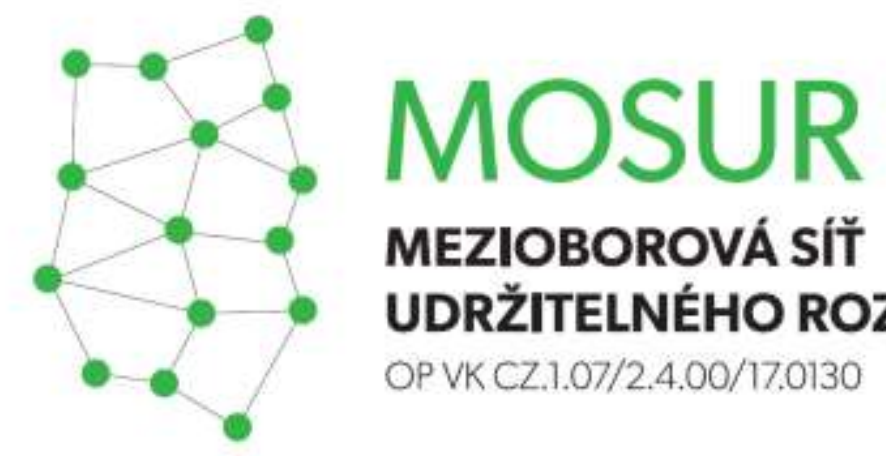

\section{MEZIOBOROVÁ SÍT} UDRŽITELNÉHO ROZVOJE

OP VK CZ.1.07/2.4.00/17.0130
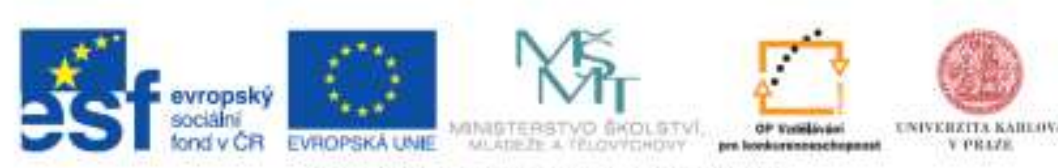

INVESTICE DO ROZVOJE VZDELAVANI 